\section{Loyalitas Kreativitas \\ Aldi Masyarakat Kreatif}

\title{
PENDIDIKAN KEWIRAUSAHAAN DAN PENGEMBANGAN KREATIFITAS SISWA DI PONDOK PESANTREN AL-MANAR CIBEUTEUNG UDI KECAMATAN CISEENG KABUPATEN BOGOR
}

\author{
Jamaludin, Sirajudin, Thamrin, Dewi Nari Ratih Permada, Masran Mustakim \\ Dosen Ekonomi Fakultas Ekonomi Universitas Pamulang \\ Emaildosen01020@unpam.ac.id,dosen01697@unpam.ac.id, \\ dosen00821@unpam.ac.id
}

\begin{abstract}
ABSTRAK
Adapun tujuan dari PKM ini adalah Meningkatkan pemahaman dan kemampuan siswa/siswi Pesantren Al- manar menjadi Pendidikan Kewirausahaan yang tepat; Meningkatkan pemahaman dan kemampuan kewirausahaan siswa/siswi dalam mengelola usaha secara efisien dan efekif; Meningkatkan pemahaman dan kemampuan wirausahawan yakni siswa/siswi Pesantren Al-manar dalam menentukan Pengembangan Kreatifitas Siswa yang efisien dan efektif.

Metode yang digunakan dalam PKM ini 1). Metode Ceramah/Presentasi Metode ceramah/presentasi dipilih untuk memberikan penjelasan tentang : a. Memberikan pengetahuan terkait dengan perencanaan pendidikan kewirausahaan dan pengembangan kreatifitas siswa. b. Presentasi mengenai perencanaan Pendidikan kewirausahaan diharapkan mereka bisa mengaplikasikan kedalam kegiatannya dalam bewirausaha; 2). Metode Tanya Jawab, Metode Tanya jawab sangat penting bagi para peserta pelatihan. Metode ini memungkinkan para siswa/i menggali pengetahuan sebanyak- banyaknya tentang perencanaan kewirausahaan, pendidikan kewiraausahaan dan pengembangan keatifitas; 3. Sharing Session Tentang Kewirausahaan

Kesimpulan dari kegiatan PKM ini adalah Pendidikan kewirausahaan sangat penting bagi manusia, terutama bagi siswa. Kewirausahaan (entrepreneurship) merupakan kemampuan kreatif dan inovaif yang dijadikan sebagai pondasi dan sumber daya untuk mendapatkan peluang dalam meraih kesuksesan. Salah satu fakor yang dapat meningkatkan pendapatan individu/kelompok ialah kewirausahaan. Kewirausahaan juga akan melahirkan kemandirian ekonomi masyarakat. Oleh sebab itu Pendidikan kewirausahaan sangat berpengaruh dalam menghasilkan kreatifitas yang bernilai dan juga pendidikan kewirausahaan adalah sebagai sesuatu yang mendasar dalam meningkatkan kreatifitas siswa.
\end{abstract}

\section{Kata kunci: pendidikan kewirausahaan, kreatifitas siswa}

\begin{abstract}
The purpose of this PKM is to improve the understanding and ability of Islamic Boarding School students to become the right Entrepreneurship Education; Improving students' entrepreneurial understanding and ability in managing businesses efficiently and effectively; Improving the understanding and ability of entrepreneurs namely students of Al-manar Islamic Boarding School in determining the efficient and effective Development of Student Creativity.

The method used in this PKM 1). Lecture / Presentation Method The lecture / presentation method was chosen to provide an explanation of: a. Provide knowledge related to entrepreneurship education planning and student creativity development. $b$. It is
\end{abstract}




\section{Loyalitas Kreativitas \\ Aldi Masyarakat Kreatif}

P-ISSN 2722-2101, E-ISSN 2722-4201

Program Studi Ekonomi Manajemen Universitas Pamulang

Jurnal LOKABMAS Kreatif Vol. 01, No. 01, Hal. 27- 35

Email:jurnalkreatif.manajemen@gmail.com

hoped that the presentation on entrepreneurship education planning can be applied to their activities in entrepreneurship; 2). Question and Answer Method, Question and Answer method is very important for the trainees. This method allows students to explore as much knowledge about entrepreneurship planning, entrepreneurship education and development activities; 3. Sharing Session About Entrepreneurship

The conclusion of this PKM activity is entrepreneurship education is very important for humans, especially for students. Entrepreneurship (entrepreneurship) is a creative and innovative ability that is used as a foundation and resources to get the opportunity to achieve success. One factor that can increase individual / group income is entrepreneurship. Entrepreneurship will also give birth to community economic independence. Therefore entrepreneurship education is very influential in producing valuable creativity and also entrepreneurship education is something that is fundamental in increasing student creativity.

\section{Keywords: entrepreneurship education, student creativity}

\section{PENDAHULUAN \\ Artinya bahwa siswa dituntut untuk}

Secara harfiah, wirausaha (enterpreneur) terdiri dari kata wira dan usaha. Dalam kamus bahasa Indonesia . (KBI, 2008) wira artinya gagah, luhur, berani,teladan atau pejuang. Sedangkan usaha diartikan sebagai kegiatan komersial atau non komersial/ kegiatan yang dilakukan terus menerus dalam mengelola sumber data untuk menghasilkan barang atau jasa yang akan dijual untuk mendapakan keuntugan. Jadi dapat diartikan wirausaha dapat diartikan sebagai orang yang berjiwa berani mengambil resiko untuk membuka usaha dalam berbagai kesempatan.

Berjiwa berani mengambil resiko artinya bermental mandiri dalam memulai usaha tanpa diliputi rasa takut atau cemas. Pada era sekarang pendidikan kewirausahaaan perlu di ajarkan kepada siswa guna memberikan pembekalan. Melihat keadaan pendidikan saat ini sangat memprihatinkan dan tidak mengalami kemajuan atau perubahan yang signifikan, disebabkan kurangnya kesadaran siswa yang membicarakan kewirausahaan dengan serius dan faktor inilah yang mempengaruhi para siswa. tentu menjadi tanggung jawab kita semua. Seharusnya pendidikan kewirausahaan sangatlah penting bagi para siswa dengan adanya pemahaman tentang kewirausahaan maka siswa diharapkan lebih peduli terhadap lingkungannya. berpikir kreatif dalam melihat peluang usaha yang memiliki nilai. Peran siswa sangat penting dalam membangun usaha. Salah satu fakor yang dapat meningkatkan pendapatan individu/kelompok ialah kewirausahaan. Kewirausahaan juga akan melahirkan kemandirian ekonomi masyarakat. Oleh sebab itu Pendidikan kewirausahaan sangat berpengaruh dalam menghasilkan kreatifitas yang bernilai dan juga pendidikan kewirausahaan adalah sebagai sesuatu yang mendasar dalam meningkatkan kemampuan individu. Instruksi presiden Nomor 4 tahun 1995 tentang Gerakan Nasional Memasyarakatkan dan membudayakan kewirausahaan, mengamatkan kepala seluruh masyarakat dan bangsa Indonesia untuk mengembangkan program- program kewirausahaan.

Pemerintah menyadari betul bahwa dunia usaha merupakan tulang punggung perekonomian nasional, sehingga harus diupayakan untuk terus menerus. Melalui gerakan ini diharapkan karakter kewirausahaan akan menjadi 2 bagian dari etos kerja masyarakat dan bangsa Indonesia, sehingga dapat melahirkan wirausahawan-wirausahawan baru yang handal, tangguh dan mandiri.

\section{RUMUSAN MASALAH}

Rumusan masalah yang akan di pecahkan melalui program ini pada 


\section{Loyalitas Kreativitas \\ Aldi Masyarakat Kreatif}

P-ISSN 2722-2101, E-ISSN 2722-4201

Program Studi Ekonomi Manajemen Universitas Pamulang

Jurnal LOKABMAS Kreatif Vol. 01, No. 01, Hal. 27- 35

Email:jurnalkreatif.manajemen@gmail.com dasarnya tidak lepas dari ruang lingkup masalah diatas, adapun perumusan masalah dalam kegiatan ini adalah:

1) Bagaimana siswa/siswi memahami pendidikan kewirausahaan yang tepat sasaran?

2) Bagaimana siswa/siswi menjadi kewirausahaan yang mampu yang mampu mengelola secara efisien dan efekif?

3) Bagaimana siswa/siswi menjadi kewirausahaan yang mampu menentukan pengembangan kreatifitas yang efektif?

\section{TUJUAN PELAKSANAAN}

Adapun tujuan dari pelaksanaan PKM ini adalah sebagai berikut:

1) Supaya siswa/siswi memahami pendidikan kewirausahaan yang tepat sasaran;

2) Supaya siswa/siswi menjadi kewirausahaan yang mampu yang mampu mengelola secara efisien dan efekif;

3) Supaya siswa/siswi menjadi wirausaha yang mampu menentukan pengembangan kreatifitas yang efektif.

\section{TINJAUAN PUSTAKA}

A. Pengertian Pendidikan Kewirausahaan Menurut Mulyani pendidikan kewirausahaan akan mendorong peserta didik, para pelajar dan mahasiswa agar mulai mengenali dan membuka usaha atau berwirausaha. Pola pikir yang selalu berorientasi menjadi karyawan diputar balik menjadi berorientasi mencari karyawan.

Dengan demikian kewirausahawan dapat diajarkan melalui nilai-nilai kewirausahaan yang akan membentuk karaker dan perilaku untuk berwirausaha agar para peserta didik kelak dapat mandiri dalam bekerja atau mandiri dalam berusaha. Menurut Kemendiknas Kewirausahaan merupakan sikap mental dan jiwa yang selalu aktif atau kreatif berdaya, bercipta, berkarya, dan bersahaja, serta berusaha dalam rangka meningkatkan pendapatan dalam kegiatan usahanya.

Menurut Kasmir (2006) kewirausahaan adalalah suatu kemampuan dalam hal menciptakan kegiatan usaha.Kemampuan menciptakan memerlukan adanya kreatifitas dan inovasi yang terus menerus untuk menemukan sesuatu yang berbeda dari yang sudah ada sebelumnya.

Menurut Muis dkk (2015) Berwirausaha adalah bukan hanya bakat bawaaan sejak lahir namun dapat dipelajari dan diajarkan melalui proses pendidikan formal atau informal. Contohnya setelah perang dunia ke 2 beberapa veteran perang di Amerika belajar berwirausaha, melalui suatu pendidikan atau pelatihan, baik pendidikan/pelatihan singkat maupun pendidikan/pelatihan yang berjenjang. Mereka berusaha dengan modal pengetahuan dan fasilias lainnya.Contoh Samuel Whalton pendiri walmart yang kini menjadi retailer terbesar dunia adalah veteran yang memulai usahanya pada usia 47 tahun. Ross Pero pendiri Texas instrument yang pernah mencalonkan diri sebagai presiden amerika dari partai independen juga seorang veteran yang berhasil dibentuk menjadi wirausaha.Ada yang mengatakan bahwa seseorang menjadi wirausaha karena lingkungan.Misalnya banyak orang WNI keturunan menjadi wirausaha yang sukses karena mereka hidup dilingkungan para wirausaha dan pelaku usaha. Menurut Retno budi lestari dan Trisnati Wijaya dalam Judul "Pengaruh Pendidikan Kewirausahaan Terhadap Minat Berwirausaha Mahasiswa di STIE 8 MDP,dan STIE MUSI ${ }^{\text {eee }}$ Penelitian di lakukakan di kota Palembang pada mahasiswa yang menempuh mata kuliah kewirausahaan pada semester genap tahun akademik 2010/2011, sebanyak 500 orang terdiri 


\section{Loyalitas Kreativitas \\ Aldi Masyarakat Kreatif}

P-ISSN 2722-2101, E-ISSN 2722-4201

Program Studi Ekonomi Manajemen Universitas Pamulang

Jurnal LOKABMAS Kreatif Vol. 01, No. 01, Hal. 27- 35

Email:jurnalkreatif.manajemen@gmail.com dari 253 mahasiswa dari STIE MDP dan 115 mahasiswa dari STIE MUSI. Pada penelitian ini di pakai instrumen penelitian yaitu, instrumen untuk mengukur sikap pribadi/ kepribadian, norma subjekif, persepsi, control perilaku dan niat dalam berwirausaha. Instrumen penelitian akan terlebih dahulu akan di analisis validitas, dan reliabilitasnya. Pengambilan data primer pada penelitian ini menggunakan instrument kuesioner yang disebar pada pada 3 PTS, dengan jumlah sampel sebanyak 205 responden.Dari penelitian ini, peneliti menyimpulkan bahwa pendidikan kewirausahaan berpengaruh secara signifikan terhadap minat berwirausaha. Pendidikan kewirausahaan yang dimaksudkan adalah proses pembelajaran untuk mengubah sikap dan pola pikir mahasiswa terhadap pilihan karier berwirausaha. Dengan demikian mahasiswa yang telah menempuh mata kuliah kewirausahaan akan memilki nilai-nilai hakiki dan karakteristik kewirausahaan sehingga akan meningkatkan minat serta kecintaan mereka terhadap dunia kewirausahaan. Tingginya minat berwirausaha akan melahirkan entrepreneur- entrepreneur muda yang memiliki visi yang jelas di masa depan, kreatifitas serta inovasi yang tinggi dalam segala bidang. Mereka akan lebih mandiri, kreatif dan inovatif dalam menciptakan peluang bisnis baru dan penemuan-penemuan baru. Masalah penggangguran terdidik akan teratasi karena keluaran (output) dari hasil pendidikan kewirausahaan adalah calon-calon enterpreneur muda berbakat yang tidak lagi mencari kerja (job seeker) tetapi telah menjadi pencipta lapangan pekerjaan (job maker). Jadi adapun persaman penelitian ini dengan penelitian yang dilakukan oleh penulis yakni samasama merujuk pada pengaruh pendidikan kewirausahaan terhadap peserta didik. Sukirman yang berjudul "Jiwa Kewirausahaan Dan Nilai Kewirausahaan Meningkatkan Kemandirian Usaha Melalui Perilaku Kewirausahaan" Penelitian ini bertujuan untuk menganalisis pengaruh jiwa kewirausahaan dan nilai kewirausahaan terhadap perilaku kewirausahawan untuk menciptakan kemandirian usaha.Metode yang digunakan dalam menganalisis data menggunakan analisis jalur (path analysis). Sampel dalam penelitian ini 125 usaha kecil yang terdiri dari 45 usaha kecil batik pekalongan, 42 usaha kecil makanan khas batu malang dan 38 usaha kecil keramik kasongan bantul Yogyakarta. Analisis data menggunakan Structural Equation Modelling (SEM).Hasil penelitian menunjukan bahwa jiwa kewirausahaan mempuyai pengaruh tidak langsung terhadap kemandirian usaha.Nilai kewirausahawan mempunyai pengaruh secara langsung terhadap perilaku kewirausahaan dan juga berpengaruh secara tidak langsung terhadap kemandirian usaha.Sedangkan perilaku kewirausahaan berpengaruh positif terhadap kemandirian usaha.Adapun persamaan dari penelitian ini dengan yang dilakukan penulis adalah memiliki kesamaan di bagian nilai/pendidikan kewirausahaan. Budi \& Fabianus fensi (2018) 10) dalam jurnal dengan judul, "Pengaruh Pendidikan Kewirausahaan Dalam menumbuhkan Minat Berwirausaha $^{\text {eeee }}$.Dalam perkembangan suatu wilayah, kewirausahaan merupakan salah satu factor penting karena hal itu merupakan penggerak ekonomi suatu wilayah, ketika kewirausahaan suatu wilayah selalu melakukan inovasi atau pembaharuan terhadap barang ataupun jasanya, otomatis dapat meningkatkan income dari wirausahawan itu sendiri dan sekaligus juga dapat meningkatkan pendapatan wilayah tersebut. Indonesia 


\section{Loyalitas Kreativitas \\ Aldi Masyarakat Kreatif}

P-ISSN 2722-2101, E-ISSN 2722-4201

Program Studi Ekonomi Manajemen Universitas Pamulang

Jurnal LOKABMAS Kreatif Vol. 01, No. 01, Hal. 27- 35

Email:jurnalkreatif.manajemen@gmail.com membutuhkan wirausaha 5,8 juta wirausaha baru untuk mencapai rasio wirausaha ideal yaitu 4\% dari jumlah penduduk. Kebutuhan untuk melahirkan kewirausahaan baru ini menyebabkan banyak lembaga pendidikan yang memasukkan pendidikan kewirausahaan dalam kurikulum mereka.Meskipun penelitian tentang kewirausahaan sudah berlangsung cukup lama, namun pendidikan kewirausahaan tetap menjadi perdebatan.Hal ini termasuk sejauh mana pendidikan kewirausahaan memiliki pengaruh terhadap peserta didik, ketepatan dan keefektifan metode pengajaran kewirausahaan, dan perdebatan apakah kewirausahaan dapat diajarkan.Penelitian ini bertujuan untuk menganalisa apakah pendidikan kewirausahaan memilki dampak untuk membangkitkan niat berwirausaha peserta didik.Subjek dalam penelitian ini adalah kelas kewirausahaan.

B. Aspek pengetahuan berwirausaha Pengetahuan sangat penting bagi manusia terutama bagi siswa dalam menjalankan kewirausahaan.

Di tahap ini siswa diberikan pengetahuan awal tentang ilmu berwirausaha seperti:

a) Business plan. Di tahap ini siswa membuat rencana atau rancangan apa yang akan mereka buat dalam usahanya mulai dari tahap awal hingga akhir dan siswa disini juga melakukan pengamatan pasar/lingkungan. Selain itu juga di bagian business plan ini siswa menyiapkan solusi ketika sesuatu masalah yang tidak inginkan terjadi.

b) Rencana srategis. Di dalam berwirasuha dibutuhkan strategi yang jitu atau yang tepat sasaran. Untuk mendukung pengamatan lingkungan/ pasar. Maka diperlukan tindak lanjut dengan siswa melakukan penjaringan pasar. Penjaringan pasar adalah sebuah sebuah versi pengamatan lingkungan dimana wirausahawan/ perusahaan mengidentifikasi pasar-pasar yang diinginkan dengan menggunakan kekuatan-kekuatan lngkungan untuk mengurangi pasar-pasar yang kurang diinginkan

c) Perencanaan merupakan ujung tombak dari kewirausahaan dimana perencanaan itu menentukan hasil yang posiif atau negatif dimasa yang akan datang. Disini siswa di tuntuk untuk melakukan perencanaan usaha apa yang akan mereka buat,dan hal pendukung lainnya. Ketika perencanaan yang dilakukan oleh siswa secara matang otomatis kemungkinan hasil yang mereka dapat dimasa yang akan datang adalah hasil yang positif. Sebaliknya, ketika perencanaan yang dilakukan siswa kurang matang atau mengalami kesalahan, otomatis hasil yang didapat dimasa yang akan datang adalah hasil yang negatif atau melenceng dari target yang di buat atau di inginkan.

C. Aspek kreatifitas Salah satu syarat utama dalam munculnya kewirausahaan adalah proses kreatifitas.

Adapun tahapan dari kreaifitas yakni:

a. Proses kreatifitas. Proses kreatifitas merupakan proses pembangkitan ide siswa di mana siswa maupun kelompok berproses menghasilkan sesuatu yang baru terutama dalam menentukan produk dalam berwirausaha dengan lebih efektif dan efisien pada suatu sistim. Aspek penting dari kreatifitas adalah manusia (manusia) dan proses. Siswa merupakan pelaku yang menentukan proses berjalan dan yang menentukan solusi permasalahan.

b. Proses Inovasi. Proses inovasi dalam wirausaha dihasilkan dari keyakinan, pemahaman tujuan yang jelas untuk menghasilkan kesempatan. Proses dapat dilihat dari kehidupan nyata. Di tahap ini siswa melakukan pertama, 


\section{Loyalitas Kreativitas \\ Aldi Masyarakat Kreatif}

P-ISSN 2722-2101, E-ISSN 2722-4201

Program Studi Ekonomi Manajemen Universitas Pamulang

Jurnal LOKABMAS Kreatif Vol. 01, No. 01, Hal. 27- 35

Email:jurnalkreatif.manajemen@gmail.com
Invention, Siswa di arahkan menciptakan produk baru, jasa atau proses untuk meningkatkan produkifitas dalam berwirausaha. Contoh: siswa membuat tempat pulpen dengan menggunakan sendok plastic. Kedua, Extention. Extention merupakan ekspansi atau perluasan dari produk, jasa atau proses dari hasil invention contoh: siswa membuat tempa buah dengan menggunakan sendok plastik. Ketiga, Duplication dan synthesis. Merupakan Proses melakukan replikasi terhadap produk, jasa, proses yang sudah ada dan melakukan kombinasi sehingga memilki kemampuan daya saing yang lebih tinggi. contoh: siswa membuat kreasi baru terhadap sandal jepit dengan menggunakan kain kanvas agar terlihat lebih menarik sehingga menghasilkan nilai jual yang lebih tinggi.

c. Ide, peluang kewirausahaan Menurut Kristanto Potensi kewirauahaan dapat digali atau membutuhkan penggalian inovasi secara nyata. Wirausaha/siswa dapat belajar mengkomidasikan dengan kesempatan yang ada pada lingkungan. Beberapa langkah prinsip memotivasi keinovasian guna mempercepat proses kewirausahaan: a) Orientasi pada tindakan (be oriented action). 4 b) membuat produk atau jasa secara sesederhana (make product, process, service simple). c) Membuat product, proses atau jasa sesuai keinginan konsumen (make the product, process, or service customers-based). d) Mulai dari hal-hal kecil (star small). e) Memiliki tujuan yang jelas, citacita tinggi (aim high). f) Belajar dari kegagalan (learn from failures). g) Memiliki schedule kerja yang teratur (follow a milestone schedule). h)

\begin{abstract}
Menghargai aktifitas dan melakukan kegiatan dengan semangat tinggi (reward heroic acivity). i) Bekerja, bekerja, bekerja (work, work, work). Jadi dalam memulai usaha siswa harus menghasilkan barang yang sesuai dengan permintaan pasar, secara umum dapat dilakukan dengan proses sistematis dan terukur.
\end{abstract}

\section{HASIL DAN PEMBAHASAN \\ Sumber: dokumentasi saat pelaksanaan PKM.}

PKM ini dirancang sebagai PKM dengan pendekatan kualitatif.

A. Solusi yang ditawarkan

Sebelum memahami tentang solusi, kita meriview tentang permasalahan yag terjadi, Adapun permasalahan yang dihadapi siswa adalah:

a. Aspek pengetahuan berwirausaha. Siswa tidak memiliki pengetahuan berwirausaha sehingga mereka tidak memahami kemampuan apa yang mereka miliki dikarenakan minimnya ilmu kewirausahaan yang mereka pahami. Dari factor tersebut otomatis akan mempengaruhi pola pikir siswa dimana pola pikir yang terbentuk adalah pola konsumtif bukan pola pikir produktif sehingga membatasi ide/gagasan yang bersifat stagnan di karenakan tidak adanya ilmu pengetahuan tentang kewirausahaan.

b. Aspek self-confident. Kurangnya kepercayaan diri siswa di sebabkan tidak adanya wadah untuk melatih kemampuan yang mereka miliki sehingga siswa tidak bisa mengekspresikan hal apa yang ada dalam pikiranya melalui tindakan, hal tersebut juga membuat Siswa kurang percaya diri untuk melakoni kewirausahaan.

c. Aspek kreatifitas. Diaspek ini siswa kurang dalam pengasahan kreatifitas. Kreatifias siswa tidak 


\section{Loyalitas Kreativitas \\ Aldi Masyarakat Kreatif}

P-ISSN 2722-2101, E-ISSN 2722-4201

Program Studi Ekonomi Manajemen Universitas Pamulang

Jurnal LOKABMAS Kreatif Vol. 01, No. 01, Hal. 27- 35

Email:jurnalkreatif.manajemen@gmail.com akan muncul kalau mereka tidak memiliki ide atau rancangan gagasan yang akan mereka buat.

B. Adapun solusi yang di tawarkan oleh Tim PKM Unpam.

Guru memberikan pegajaran kewirausahaan melalui brainstorming metode dan melakukan pendampingan kepada siswa. Metode tukar pikiran (brainstorming) merupakan metode yang paling terkenal dan efekif untuk memunculkan berbagai ide tentang suatu masalah dalam waktu yang terbatas melalui peran serta partisipan secara spontan.

Metode brainstorming ini juga merupakan metode kelompok untuk mendapakan berbagai ide dan solusi baru (Hisrich et. Al 2008). Menurut Harianti A \& Margaretha Y (2014) Pada metode ini peserta dalam kelompok dapat disimulasi agar dapat memperlihatkan kreativitas yang lebih baik melalui pertemuan dengan orang lain, dan partisipasi dalam pengalamanpengalaman kelompok.

Adapun hal yang harus diperhatikan dalam berwirausaha terutama bagi siswa dalam meningkatkan kreatifitas yakni:

1. Kemampuan melihat pasar potensial

2. Jenis produk( barang )yang dibutuhkan dalam pasar.

3. Minat konsumen terhadap produk(barang) yang diinginkan.

4. Daya beli konsumen di pasar tertentu.

5. Saingan usaha sejenis dalam pasar tersebut.

C. Ciri-Ciri Wirausahawan

Adapun ciri-ciri wirausahawan adalah sbb:
a. percaya diri
b. Secara terus menerus melihat peluang yang tidak dapat dilihat oleh orang lain.

c. Tidak pernah merasa puas, dan selalu dapa mengeksploiasi perubahan yang ada.

d. Selalu mempunyai komitmen untuk menang.

e. Mempunyai intuisi tajam.

f. Action oriented.

g. Dapat memanfaatkan ancaman menjadi peluang.

\section{KESIMPULAN DAN SARAN \\ Kesimpulan}

Dalam memasuki dunia kewirausahaan siswa diuntut untuk tidak hanya memilki kemampuan tetapi siswa harus memiliki ide dan kemauan, ide dan kemauan itulah yang akan di wujudkan dalam bentuk penciptaan atau pembuatan barang dan jasa yang laku dipasar.

Hal ini merupakan hasil dari kreatifitas. Selain itu, modal dibutuhkan dalam berwirausaha. Dalam hal ini modal yang dimaksud bukan hanya berupa uang tetapi juga bisa berupa barang, orang (tenaga kerja/skill) dan juga bisa berupa fasilitas. Selanjunya Barang dan jasa, Dalam menentukan barang dan jasa yang akan dijadikan sebagai objek kewirausahaan tentunya siswa harus memiliki pasar( konsumen dan laku dipasarkan) untuk memasarkan produk/jasa tersebut. Kemudian adapun hal tambahan yang harus di perhatikan siswa dalam berwirausaha yakni Pasar. Siswa sebelum menciptakan produk harus mengamati peluang pasar yang sedang banyak diminati oleh konsumen. Dan yang terakhir adalah Provit,bila siswa sudah melihat peluang pasar maka tinggal memproduksi barang/produk yang telah di tentukan sebagai sasaran kewirausahaan. Produk/barang ini merupakan hasil kreatifitas siswa dengan melihat berbagai macam factor kewirausahaan untuk meningkatkan keuntungan dalm berwirausaha.

Dari hasil PKM tentang pelatihan

"Pendidikan Kewirausahaan Dan

Pengembangan Kreatifitas Siswa Di

Pondok Pesantren Al-Manar Cibeuteung 
Udik Kecamatan Ciseeng Kabupaten Bogor disimpulkan sebagai berikut:

1. Para pesera mendapakan pendalamaman ilmu terkait dengan Pendidikan kewirausahaan dan pengembangan kreatifitas siswa.

2. Adanya peningkatan pengetahuan para peserta terkait cara membuat pendidikan Kewirausahaan yang baik terutama bagi siswa/i yang belum pernah membuat perencanaan bisnis dan belum memilki usaha.

3. Para peserta merasa puas dengan materi yang diberikan oleh para dosen universitas pamulang, hal ini dilihat dari hasil kuesioner yang kami sebar kepada para peserta.

\section{Saran}

Saran untuk kegiatan PKM kedepanya adalah sebagai berikut:

1. Perluya berkesesinambugan pemantauan terhadap pelaksanaan perencanaan bisnis siswa/i, agar bisnis mereka biar terus berjalan dengan baik.

2. Kedepannya bisa terjadi kolaborasi kegiatan lain antara pesantren Almanar dengan Universitas Pamulang dan mendatangkan para Pengusaha yang sukses

3. siswa/ peserta didik perlu belajar tentang kewirausahaan sejak dini

4. melatih siswa menuangkan ide dalam membuat kreatifitas atau inovasi terhadap barang dan jasa,

5. membentuk kemandirian,

6. melatih siswa besosialisasi dengan lingkungan, dan yang paling utama adalah membangkitkan niat berwirausaha.

\section{DAFTAR PUSTAKA}

Budi\&Fensi, F (2018). Kewirausahaan Dalam menumbuhkan Minat Berwirausaha. Jurnal Pengabdian dan Kewirausahaan (Online). Universitas Bunda Mulia. Jakarta. Vol https://journalubm.ac.id/index.php/p engabdiandankewirausahaan/article/ view/1128/989. 22 oktober 2019.

Harianti A \& Margaretha Y. (2014). Pengembangan Kreatifitas Mahasiswa dengan Menggunakan Metode Brainstorming dalam Maa Kuliah Kewirausahaan. Universitas Kristen Maranatha. Bandung. Vol 13. No.2.

Muis, A dkk. 2014. Ibk Pengembangan Kewirausahaan Bagi Mahasiswa dan Alumni di Universita Muhammadiyah Parepare. Jurnal Kemandirian. https://www.academia. Edu/30603803/ibk_pe. 1 Desember 2019.

Sukirman. 2017. Jiwa Kewirausahaan Dan Nilai Kewirausahaan Meningkatkan Kemandirian Usaha Melalui Perilaku Kewirausahaan. jurnal of fakultas ekonomi. Universias Muria Kudus. Vol.20. 22 oktober 2019.

Pasaribu, V. L. D., Agrasadya, A., Shabrina, N., \& Krisnaldy, K. (2020). MENJADI ENTERPRENEUR MUDA YANG MEMILIKI JIWA LEADERSHIP UNTUK MENGHADAPI MASA DEPAN. Abdi Laksana, 1(1)

Pasaribu, V. L. D., Elburdah, R. P., Sudarso, E., \& Fauziah, G. (2020). PENGGUNAAN MANAJEMEN WAKTU TERHADAP PENINGKATAN PRESTASI BELAJAR DI SMP ARAISIYAH. Jurnal ABDIMAS, 1(1)

Pasaribu, V. L. D., Susanti, F., \& Hartuti, E. T. K. (2019). MEMOTIVASI SISWA DAN SISWI SMK LETRIS INDONESIA DI DALAM MENENTUKAN PILIHAN UNTUK MELANJUTKAN PENDIDIKAN ATAU BEKERJA SETELAH LULUS SEKOLAH. Jurnal 


\section{Loyalitas Kreativitas \\ Aldi Masyarakat Kreatif}

P-ISSN 2722-2101, E-ISSN 2722-4201

Program Studi Ekonomi Manajemen Universitas Pamulang Jurnal LOKABMAS Kreatif Vol. 01, No. 01, Hal. 27- 35

Email:jurnalkreatif.manajemen@gmail.com

Pengabdian Dharma Laksana, 1(2), 161-

172.

\section{DOKUMENTASI FOTO KEGIATAN}
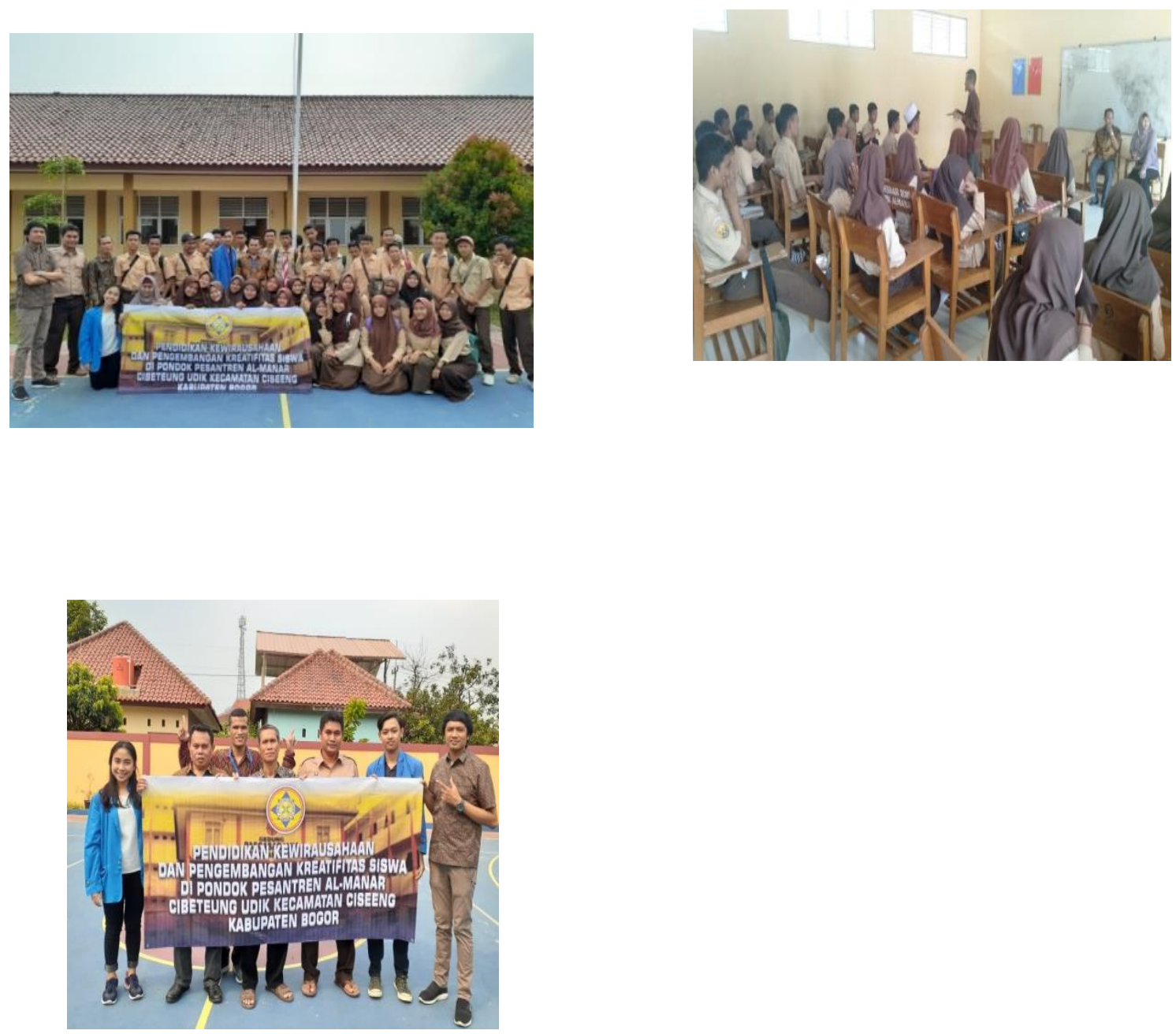